\title{
A study on the nutritional characteristics of some plants and their effects on ruminal microbial fermentation and protozoa population
}

\author{
Mohsen Kazemi $^{1 *} \mathbb{D}$, Mohammad Mehdi Moheghi ${ }^{2}$ and Reza Tohidi ${ }^{1}$
}

\begin{abstract}
We designed this project to determine the nutritional potential and ruminal microbial fermentation properties of eight rangeland plants (Dracocephalum moldavica L., Melissa officinalis L., Ruta graveolens L., Perovskia abrotanoides Kar., Cichorium intybus L., Borago officinalis L., Peganum harmala L., and Teucrium polium L.) collected from the semi-arid region of Iran at two consecutive years (2019 and 2020) for ruminant diets. Medicago sativa as a common forage was also considered as control. We determined the chemical-mineral composition, buffering capacity, in vitro gas yield, ruminal fermentation, and protozoa population in a culture medium with the standard laboratory methods. A significant difference in chemical-mineral compounds was observed among the studied plants $(p<0.05)$. A lower crude protein range (6.28\% for Cichorium intybus L. to $18.4 \%$ for Melissa officinalis L.) was observed rather than Medicago sativa (20.3\%). The amount of calcium was highest in Peganum harmala L. (23.5-24.2 g/kg DM) and lowest in Ruta graveolens L. (1.15-1.25 g/kg DM). Dracocephalum moldavica L. exhibited the highest acid-base buffering capacity $\left(235-242 \mathrm{mEq} \times 10^{-3}\right)$ among other plants. The highest decrease in total protozoa and other protozoan populations was observed when Perovskia abrotanoides Kar. was added to the culture medium. Teucrium Polium L. had the greatest potential gas yield and its total volatile fatty acid was comparable with Medicago sativa. It seems that eight plants are nutritionally suitable for partial replacement of the conventional plants such as Medicago sativa in diets of small ruminants, however dietary supplementation of Peganum harmala L. due to its alkaloids content should be done with caution.
\end{abstract}

Keywords: Plants, Ruminant, Nutritional potential, Protozoa, Culture medium

\section{Introduction}

In the semi-arid and arid regions of Iran, there is an intense shortage of suitable forages for animal production. Also, in recent years, the carrying capacity of natural pastures and nutritional value of the rangelands has been restricted due to severe droughts, improper overgrazing, and lack of a proper grazing program (Habib

\footnotetext{
*Correspondence: phd1388@gmail.com

1 Department of Animal Science, Faculty of Agriculture and Animal

Science, University of Torbat-e Jam, Torbat-e Jam, Iran

Full list of author information is available at the end of the article
}

et al. 2016). The natural pastures in the mountainous region of Iran provide an essential forage resource for small ruminants that complement lowland livestock systems during the grazing period (Kazemi 2019). Torbat-e Jam mountainous rangelands consist of herbs, shrubs, grasses, and trees which often have suitable biodiversity. Small ruminants in this region often obtain their feedstuffs through grazing on native pastures. Several studies on the nutritive value of some rangeland plants as feed sources for ruminants were recently conducted in Iran (Kazemi 2019; Kazemi and Valizadeh 2019; Kazemi 2021). Despite the ecological importance as a habitat for 
biodiversity flora and fauna, the Iranian rangelands consist of different plants containing a nutritional potential that can meet the nutrient requirements of small ruminants (Kazemi 2019; Kazemi and Valizadeh 2019). The use of rangeland plants in diets of ruminants depends on their chemical/mineral compounds and nutrient digestibility. The chemical composition and ruminal microbial fermentation parameters of plants can be diverse because of differences in the plant variety, environmental and weather situations (Keim et al. 2018). For example, the in vitro dry matter degradability of some range plants varied from 711 to $828 \mathrm{~g} / \mathrm{kg}$ DM among the plants collected in the semi-arid pastures of Torbat-e Jam, Iran. Although different range plants exist in Iran, less attention has been paid to their nutritional aspects worldwide. Therefore, the objective of this study was to collect samples of eight rangeland plants in two consecutive years to determine their chemical-mineral compounds and buffering capacity and test their effects on ruminal microbial fermentation parameters and protozoa populations in vitro.

\section{Material and methods}

\section{Area and plants collection}

The whole samples of eight plant species including Dracocephalum moldavica L., Melissa officinalis L., Ruta graveolens L., Perovskia abrotanoides Kar., Cichorium intybus L., Borago officinalis L., Peganum harmala L., and Teucrium polium L., were randomly collected during the flowering stage from mountain pastures of Torbate Jam (Mian Jam rural district, altitude approximately $1200 \mathrm{~m}$ above sea level with semi-arid weather) located in the province of Razavi Khorasan between 2019 and 2020 (June to August). Medicago sativa was also collected from the surrounding lands of studied plants during the flowering stage.

\section{Laboratory protocols Chemical composition}

The whole samples related to each plant in each year were mixed, transferred to the laboratory, and then dried at $60{ }^{\circ} \mathrm{C}$ in a forced oven (Behdad Co., Iran) for $48 \mathrm{~h}$. After that, the samples were milled through a $1 \mathrm{~mm}$ screen (Willey mill), transferred to the nylon bags, and preserved in a dark place until the subsequent experiments. We determined dry matter (DM) related to each plant by a forced oven at $105{ }^{\circ} \mathrm{C}$ until constant weight (AOAC 2005). The protocols suggested by AOAC (2005) were employed for ether extract (EE), ash, and crude protein $(\mathrm{CP}$, Kjeldahl $\mathrm{N} \times 6.25)$ concentrations. The concentrations of neutral detergent fiber (NDF), acid detergent lignin (ADL), and acid detergent fiber (ADF) were measured according to Ankom procedures (Ankom Technology 2005, 2006a, b).

\section{Mineral composition and buffering capacity}

The mineral concentrations of samples (sodium, magnesium, calcium, potassium, iron, zinc, manganese, and cobalt) were measured using atomic absorption (SavantAA, GBC, Australia). The phosphorus content was determined by UV-Vis spectrophotometry. The suggested method by Jasaitis et al. (1987) was considered for buffering characteristics and $\mathrm{pH}$ determination (Table 3).

\section{In vitro assay}

Two fistulated Baluchi male sheep were selected for rumen fluid gathering before the morning meal. Sheep were fed a diet containing $60 \%$ forage to $40 \%$ concentrate based on National Research Council (NRC 2007) recommendations at the maintenance level. The collected rumen fluid was strained through four-layer of cheesecloth and then transferred to the laboratory. The method suggested by Menke and Steingass (1988) was used for the gas test technique. In brief, $200 \mathrm{mg}$ of the milled sample $(1 \mathrm{~mm}$ screen) was moved into a $100 \mathrm{ml}$ glass syringe. The rumen fluid and artificial saliva at a ratio of $1: 2 \mathrm{w} / \mathrm{w}$ was added to each syringe under $\mathrm{CO}_{2}$ flow and was immediately closed with rubber caps and crimped. All glass syringes were transferred to a water bath at $39{ }^{\circ} \mathrm{C}$. The gas production volume was recorded after 3, 6, 9, $12,24,48,72$, and $96 \mathrm{~h}$ of incubation. Four replications at two runs were used for each plant species. Also, four glass syringes without samples were selected for blank. Four syringes in each run were separately considered for ruminal fermentation determination. After $24 \mathrm{~h}$ incubation, the related syringes were emptied, and their contents filtered through a Buchner funnel assembled with a polyester cloth (45-micron pore size, Kazemi and Ghasemi Bezdi 2021). The content gathered above the polyester cloth was transferred into the pre-weighed crucible, washed with the neutral detergent solution, dried in oven at $60{ }^{\circ} \mathrm{C}$ (Makkar 2010) for $48 \mathrm{~h}$, and then true dry matter digestibility (TDMD) was determined. The $\mathrm{pH}$ of the in vitro rumen fluid was measured by a $\mathrm{pH}$ meter (Hana, Model HI 2210-01, USA) after 24 h of incubation. Ten $\mathrm{ml}$ of the strained solution was mixed with $10 \mathrm{ml}$ of $0.2 \mathrm{~N}$ $\mathrm{HCl}$ and preserved at $-18{ }^{\circ} \mathrm{C}$ until ammonia analysis (Komolong et al. 2001). Total protozoa and other genera in the culture medium ( $24 \mathrm{~h}$ incubation) were enumerated using a light microscope and a hemocytometer (Neubauer-improved, Marienfeld, Germany), according to the method described by Dehority (2003). In brief, two $\mathrm{mL}$ of each syringe content was pipetted into a screwcapped test tube containing $5 \mathrm{~mL}$ of formalized physiological saline $(20 \mathrm{~mL}$ of formaldehyde in $100 \mathrm{~mL}$ of saline 


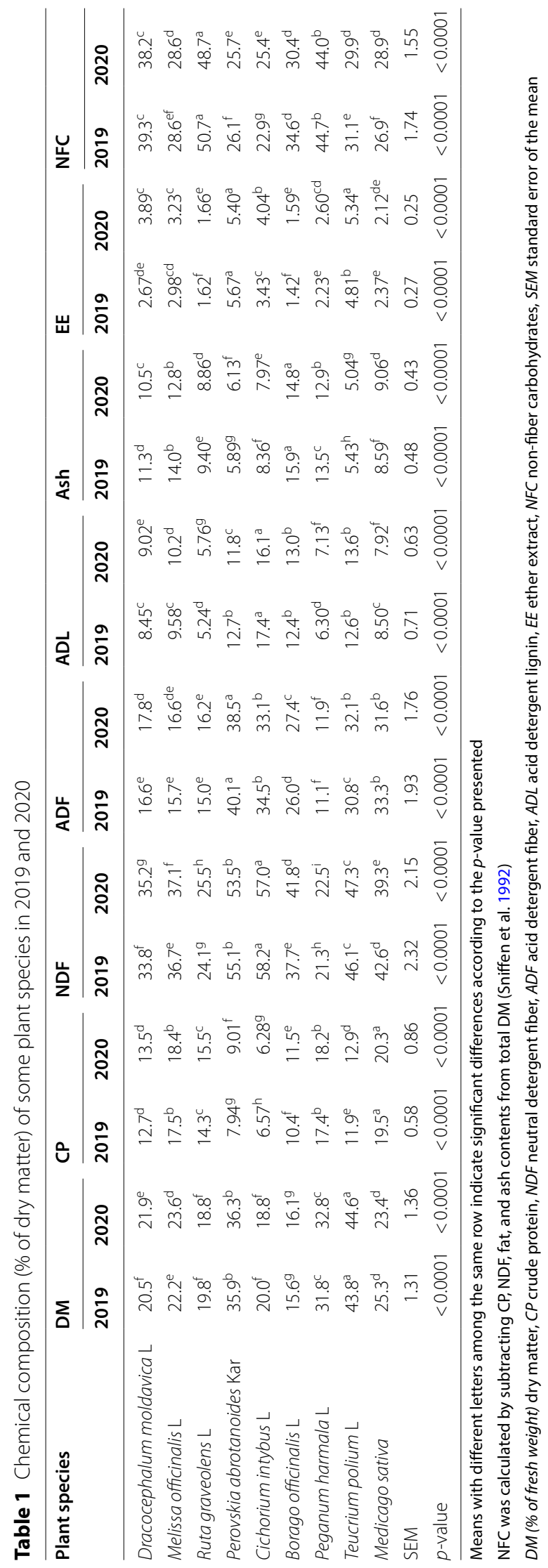


containing $0.85 \mathrm{~g}$ of $\mathrm{NaCl}$ in $100 \mathrm{~mL}$ of distilled water). Thereafter, two drops of brilliant green dye solution were added to the test tube, mixed thoroughly, and allowed to stand overnight at room temperature. The method suggested by Getachew et al. (2004) was employed for sampling from rumen fluid and its preparation for ingredients and total volatile fatty acids (TVFA) determination. The volatile fatty acids (VFA) concentrations were determined by gas chromatography (YL6100 GC, Young Lin Instrument, Anyang, South Korea) fitted with a $50 \mathrm{~m}$ Silica-fused (0.32 mm internal diameter) column chromatography (CP-Wax Chrom-pack Capillary Column, Varian, Palo Alto, CA, USA). Helium was used as a gas carrier. Crotonic acid was used as an internal standard. The initial and final oven temperatures were set at 55 and $195^{\circ} \mathrm{C}$, respectively. The temperature of the detector and injector was set at $250{ }^{\circ} \mathrm{C}$. The data gathered from the gas test were analyzed using the equation $P=b\left(1-e^{-c t}\right)$, in which $P$ is the volume of gas produced at time $t, b$ the potential gas production after $96 \mathrm{~h}$ incubation $\left(\mathrm{b}_{\text {gas }}\right.$, $\mathrm{ml} / 200 \mathrm{mg} \mathrm{DM}), c$ the fractional rate of gas production $\left(\mathrm{c}_{\text {gas }}, \% / \mathrm{h}\right)$, and $t$ the incubation time (h) (Ørskov and McDonald 1979).

\section{Statistical analysis}

The chemical-mineral and buffering capacity were replicated in quadruplicate. The data relating to the gas test were repeated in two runs (four replicates in each run). All data were evaluated for their normality using the Shapiro-Wilk test and then were analyzed in a completely randomized design using SAS software (SAS Institute Inc 2002) with the following model: $Y_{i j}=\mu+T_{i}+e_{i j}$ where; $Y_{i j}=$ the value of each observation, $\mu=$ total mean, $\mathrm{Ti}=$ treatment effect and $\mathrm{e}_{\mathrm{ij}}=$ experimental error. Statistical differences between treatments were determined at $p<0.05$ using the Duncan test. Each plant species was considered as a treatment.

\section{Results}

\section{Chemical compound}

The chemical composition of some plant species in 2019 and 2020 is presented in Table 1. A different range of chemical composition was observed among the plant species. The DM content of plants was differed from $15.6 \%$ for Borago officinalis L. to $44.6 \%$ for Teucrium polium L. Consistently, in both harvest years (2019 and 2020), CP contents in Medicago sativa (19.5-20.3\%) were found to be among the highest across the experimental plants, followed by Melissa officinalis L. (17.5-18.4\%) and Peganum harmala L. (17.4-18.2\%, $p<0.0001)$. The highest content of NDF, ADF, and ADL was observed in Cichorium intybus L. (57-58.2\%) and Perovskia abrotanoides Kar. (38.5-40.1\%) and Cichorium intybus L.
(16.1-17.4\%), respectively $(p<0.0001)$. The ash, EE, and non-fiber carbohydrates (NFC) concentrations were highest in Borago officinalis L. (14.8-15.9\%) Perovskia abrotanoides Kar. (5.40-5.67\%), and Ruta graveolens L. $(48.7-50.7 \%)$, respectively $(p<0.0001)$.

\section{Mineral compound and buffering capacity}

The mineral composition and buffering capacity of some plant species in 2019 and 2020 are presented in Tables 2 and 3, respectively. The contents of calcium and phosphorus were highest in Peganum harmala L. (23.5$24.2 \mathrm{~g} / \mathrm{kg}$ DM) and Teucrium polium L. (7.17-7.67 g/ kg DM), respectively $(p<0.0001)$. Borago officinalis $\mathrm{L}$. exhibited the highest potassium (28.4-28.9 g/kg DM) and zinc (73.3-75.7 $\mathrm{mg} / \mathrm{kg} \mathrm{DM})$ among other plants $(p<0.0001)$. The contents of manganese $(75.3-85.3 \mathrm{mg} /$ $\mathrm{kg}$ DM) and iron (323-385 mg/kg DM) were highest in Melissa officinalis L. compared to Medicago sativa $(p<0.0001)$. The magnesium content varied from 1.66 for Medicago sativa to $12.4 \mathrm{~g} / \mathrm{kg}$ DM for Dracocephalum moldavica $\mathrm{L}$. The $\mathrm{pH}$ value of plants was different from 4.85 for Ruta graveolens L. to 5.82 for Medicago sativa. Titratable acidity was in the range of 128 for Cichorium intybus L. to $344 \mathrm{mEq} \times 10^{-3}$ for Borago officinalis L. The highest values related to acid-buffering capacity (189-199 $\left.\mathrm{mEq} \times 10^{-3}\right)$ and acid-base buffering capacity $\left(235-242 \mathrm{mEq} \times 10^{-3}\right)$ was observed in Dracocephalum moldavica L. $(p<0.0001)$. Titratable alkalinity (205-224 $\left.\mathrm{mEq} \times 10^{-3}\right)$ was highest in Ruta graveolens L. $(p<0.0001)$. Medicago sativa exhibited the highest basebuffering capacity $\left(55.7-58.8 \mathrm{mEq} \times 10^{-3}, p<0.0001\right)$.

\section{Protozoa population}

Protozoa population of the culture medium after plant incubation are presented in Table 4. Total protozoa and other protozoa populations of the culture medium were changed when some plants were incubated. Perovskia abrotanoides Kar., Cichorium intybus L., Peganum harmala L., and Teucrium polium L. had a decreasing effect on total population, Entodinium spec., Diplodinium spec., Epidinium spec., Ophryoscolex spec., Isotricha spec., and Dasytrichia spec., compared to Medicago sativa as control plants. The results indicated that Perovskia abrotanoides Kar. had the highest decreasing effect on protozoa populations among the studied plants $(p<0.0001)$.

\section{In vitro gas production and fermentation parameters}

In vitro gas production, ammonia nitrogen, and TDMD of some plants in a culture medium are presented in Table 5. The highest content of $b_{\text {gas }}(39.1-39.9 \mathrm{ml} / 200 \mathrm{mgDM})$ and $24 \mathrm{~h}$ gas production (30.5-31 ml/200 mg DM) were observed in Teucrium polium L. $(p<0.0001)$. The 


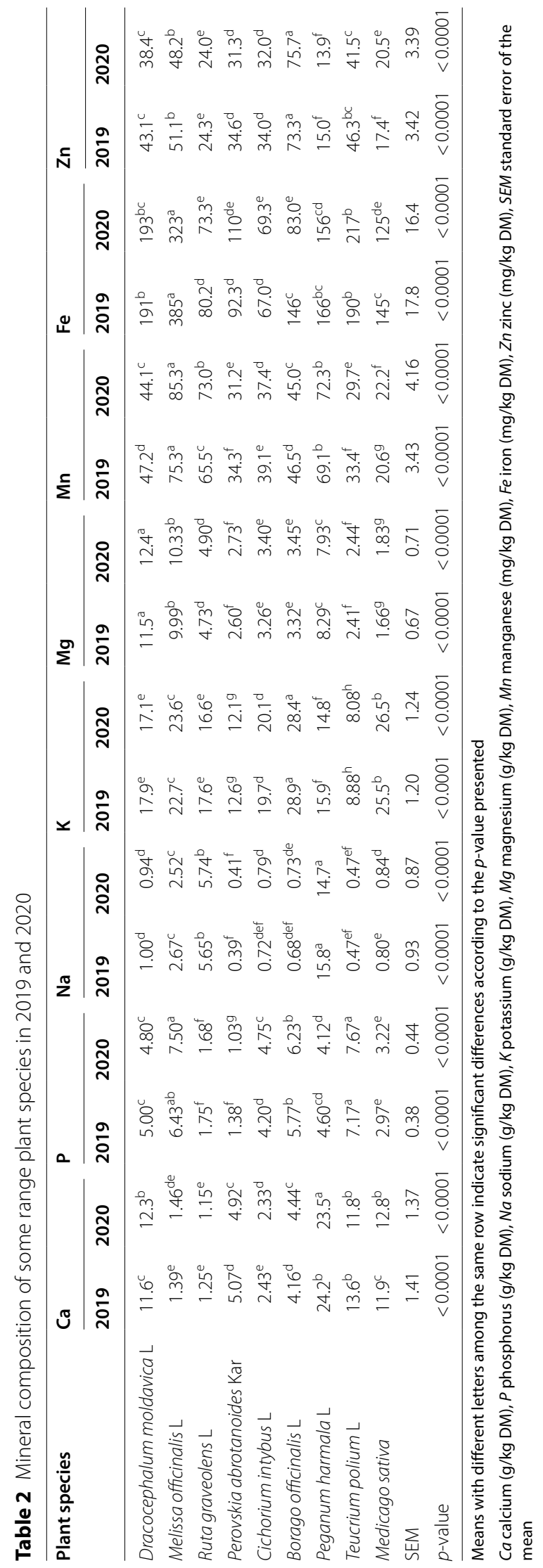




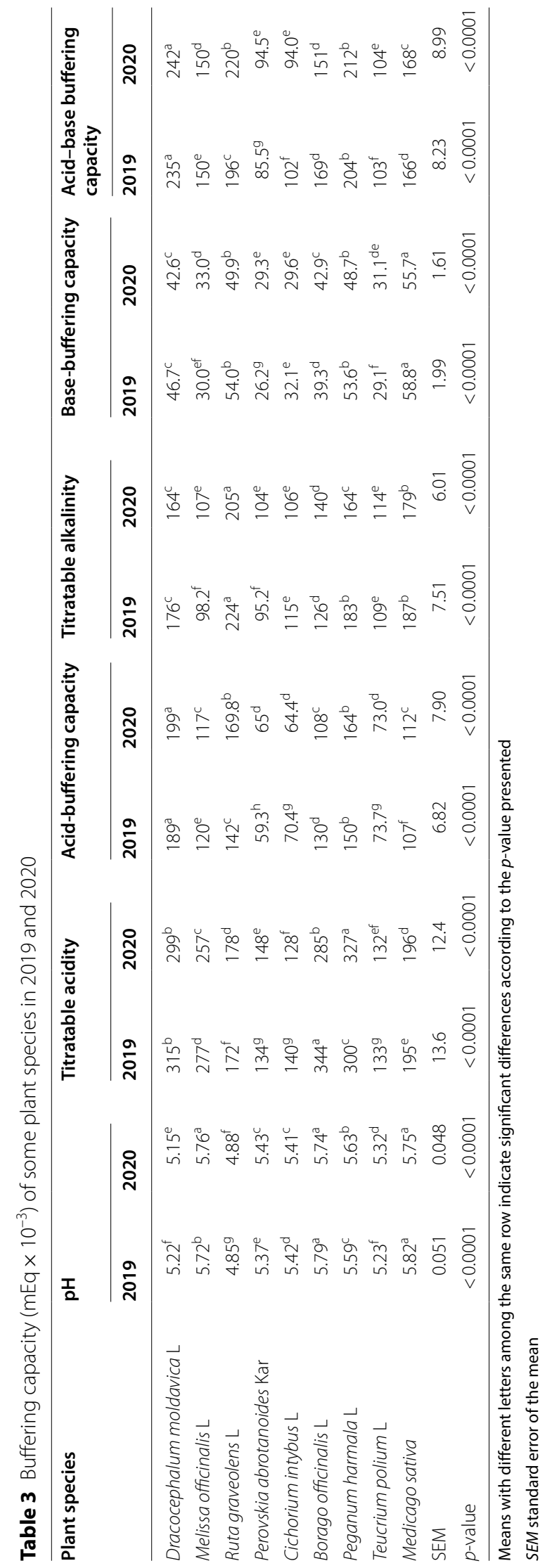


ammonia nitrogen in the culture medium ranged from $18.5 \mathrm{mg} / \mathrm{dl}$ for Cichorium intybus $\mathrm{L}$. to $31.7 \mathrm{mg} / \mathrm{dl}$ for Medicago sativa. The content of TDMD also ranged from $57.2 \%$ for Cichorium intybus L. to $86.8 \%$ for Peganum harmala $\mathrm{L}$. The measured TVFA and their ingredients from some plants incubated in the culture medium are presented in Table 6. The concentration of TVFA (51.8 for Perovskia abrotanoides Kar. to 64.5 for Ruta graveolens L.) was different among the incubated plants. The produced acetate and propionate in the culture medium were different among the plant species.

\section{Discussion}

Despite the increasing scientific interest in range plants as forage feed, the chemical composition and nutritional properties of some range plants have not yet been commonly studied. We decided to evaluate the nutritional properties of eight plant species of different genera compared to alfalfa. As expected, the overall variation in the chemical composition of plant species between 2019 and 2020 was low. Melissa officinalis L. (17.5-18.4\%) and Peganum harmala L. (17.4-18.2\%) were rich sources of CP compared to Medicago sativa. In contrast with our study, the CP content of different Melissa officinalis L. samples was reported to be 4.14-7.74\% DM (Dias et al. 2012). In our study, a higher fat content for Melissa officinalis $\mathrm{L}$. was observed compared to the previous study (Dias et al. 2012). The range of NDF (21.3-58.2\%), ADF (11.1-40.1\%), and ADL (5.24-17.4\%) concentrations of present plants are in agreement with other reports (Kazemi 2019; Kazemi and Valizadeh 2019). Kazemi (2019) reported that the chemical composition of plants can alter in different weather and different harvesting time. Considering a minimum level of CP $(7-8 \%$ of $\mathrm{DM})$ required for a balanced rumen function and dry matter intake (DMI) in small ruminants, the concentration of CP in the present plants can be helpful in this regard (Van Soest 1994). The higher content of NDF in Cichorium intybus L. can be attributed to the lower leaf to stem ratio. Part of the high levels of fat in Perovskia abrotanoides Kar and Teucrium polium L. can be attributed to the high amounts of essential oils that have been previously reported by researchers (Ghaffari et al. 2018; Mahmoudi and Nosratpour 2013). The forage digestibility and DMI in ruminants are influenced mainly by the dietary NDF (Harper and McNeill 2015). We found a reasonable range of NDF among the present plants. Feeds and forages like of present plants are extensively different in their amount and composition of NFC, and carbohydrates fractions in NFC vary in rate and extent of ruminal fermentation, fermentation products, and contribution in microbial yield (Hall and Herejk 2001; Nocek and Tamminga 1991), and therefore in ruminants performance.
Forages supply a significant source of minerals for livestock. The bioavailability of forage minerals to ruminants may be affected by the distribution of minerals within the forage and the chemical form of the elements present (Spears 1994; Khan et al. 2005). In the present study, we found a diverse range of minerals among the studied plants. Awareness of mineral requirements and the bioavailability of forages will allow animal nutritionists to formulate mineral supplements that maximize animal performance. Therefore, the reported data about the mineral contents of the present plants (Table 2) can be helpful for nutritionists in preparing a balanced diet. In the present study, the level of potassium in all the plants was above the critical levels $(6-8 \mathrm{~g} / \mathrm{kg} \mathrm{DM})$ recommended for grazing animals (McDowell 1992, 1997). However, it has been reported that high-yielding animals under heat stress require potassium above $10 \mathrm{~g} / \mathrm{kg}$ DM (Mirzaei 2012). The present plants contained suitable levels of Fe (67-385 mg/kg DM) as the recommended level of iron for ruminants was $30 \mathrm{mg} / \mathrm{kg}$ DM (McDowell 1985). It is reported that the forage manganese level between 30 and $40 \mathrm{mg} / \mathrm{kg}$ can meet the manganese requirements of ruminants (McDowell 1985). In this study, except Medicago sativa, the manganese content of other plants was above $30 \mathrm{mg} / \mathrm{kg}$ DM. A recommended sodium requirement for grazing ruminants has been reported between 0.4 and $1.8 \mathrm{~g} / \mathrm{kg} \mathrm{DM}$ (McDowell 1985). We found that all studied plants had a $\mathrm{Na}$ content above $0.4 \mathrm{~g} / \mathrm{kg} \mathrm{DM}$, and they will be able to meet the sodium requirements of ruminants quickly. The critical dietary level of phosphorus concentration is $2.5 \mathrm{~g} / \mathrm{kg}$ DM (McDowell 1992, 1997), and it is reported that the phosphorus requirement of a grazing ruminant is rarely met by forages. So supplementation of $1 \mathrm{~kg}$ of diets (DM basis) with Dracocephalum moldavica L., Melissa officinalis L., Cichorium intybus L., Borago officinalis L., Peganum harmala L., Teucrium polium L., and Medicago sativa can meet the phosphorus requirements of ruminants. Calcium and phosphorus play crucial roles in most body tissues with structural functions in cell membranes, bones, and teeth (McDowell and Arthington 2005). They are involved in cellular processes including membrane potential, DNA synthesis, cell membrane fluidity, intracellular communication, and biochemical pathways (Underwood and Suttle 1999). Minson (1990) reported that among the 263 samples, only $31 \%$ of forages were low in calcium (less than $3 \mathrm{~g} /$ kg DM). We found that only Melissa officinalis L., Ruta graveolens L., and Cichorium intybus L. had calcium content below critical concentrations ( $3 \mathrm{~g} / \mathrm{kg} \mathrm{DM})$. Except for Medicago sativa, the magnesium concentration of all present plants is well more than the critical level (2 g/ kg DM; McDowell 1992, 1997) for grazing animals. The critical level of zinc for ruminants has been reported at 


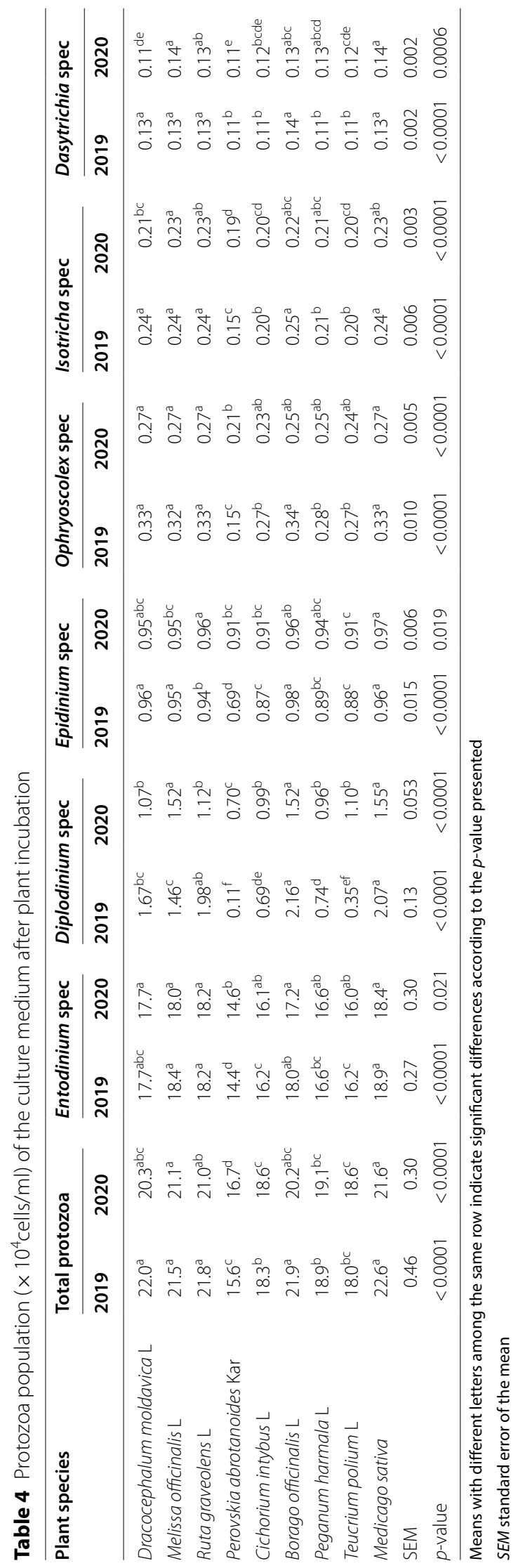




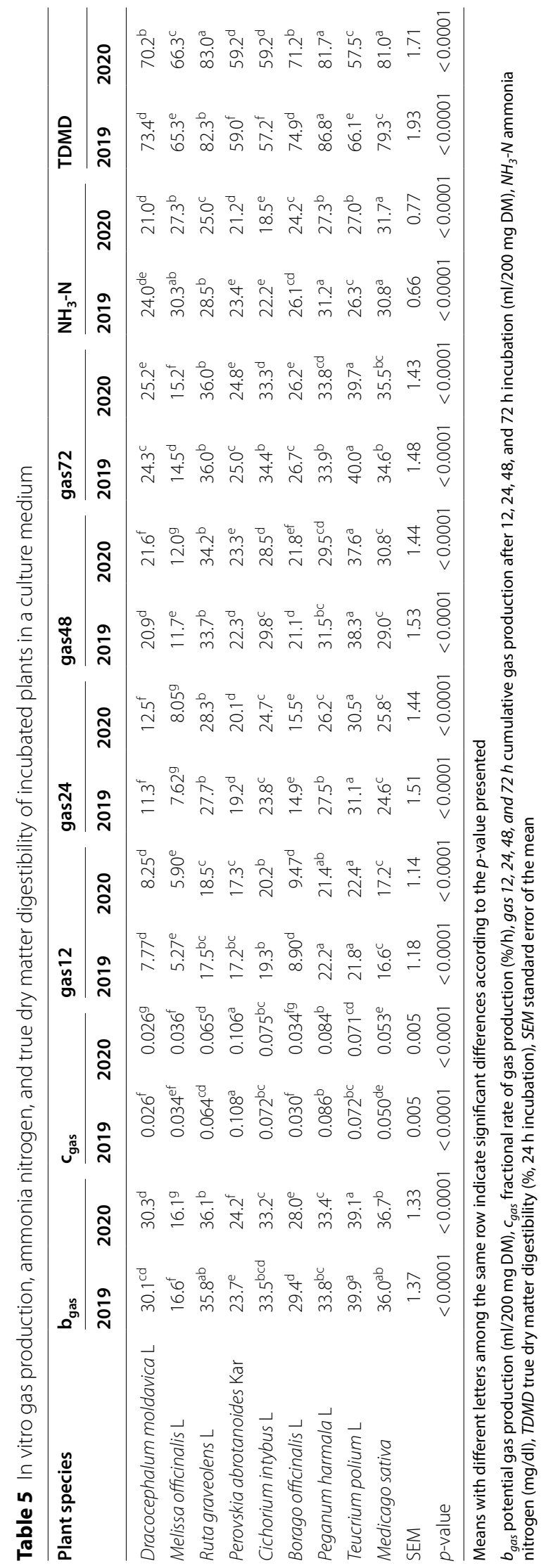


Table 6 The measured total volatile fatty acids ( $\mathrm{mmol} / \mathrm{l})$ and their ingredients (\% of TVFA) from some plants incubated in the culture medium after $24 \mathrm{~h}$ incubation

\begin{tabular}{|c|c|c|c|c|c|c|c|c|c|c|c|c|c|c|}
\hline \multirow[t]{2}{*}{ Plant species } & \multicolumn{2}{|l|}{ TVFA } & \multicolumn{2}{|c|}{ Acetate } & \multicolumn{2}{|c|}{ Propionate } & \multicolumn{2}{|c|}{ Butyrate } & \multicolumn{2}{|c|}{ Valerate } & \multicolumn{2}{|c|}{ iso-Valerate } & \multicolumn{2}{|l|}{$\mathrm{pH} 24 \mathrm{~h}$} \\
\hline & 2019 & 2020 & 19 & 2020 & 19 & 2020 & 2019 & 2020 & 2019 & 2020 & 2019 & 2020 & 2019 & 2020 \\
\hline racocephalum moldavica $\mathrm{L}$ & $58.1^{d}$ & $53.7^{d}$ & (05.3 & $63.0^{\mathrm{a}}$ & $19.8^{\circ}$ & $19.7^{\mathrm{abc}}$ & 13.9 & 14.0 & 1.25 & 1.20 & 0.40 & 0.38 & $6.90^{\mathrm{a}}$ & $6.87^{\mathrm{a}}$ \\
\hline Melissa officinalis $\mathrm{L}$ & $61.5^{b}$ & $56.9^{c}$ & $64.0^{\mathrm{a}}$ & $62.8^{\mathrm{a}}$ & $19.3^{b}$ & $18.0^{c}$ & 13.8 & 14.7 & 1.20 & 1.30 & 0.45 & 0.38 & $6.92^{\mathrm{a}}$ & $6.91^{\mathrm{a}}$ \\
\hline Ruta graveolens $\mathrm{L}$ & $64.5^{\mathrm{a}}$ & $60.5^{\mathrm{ab}}$ & $60.5^{c}$ & $60.8^{c}$ & $23.7^{\mathrm{a}}$ & $21.4^{\mathrm{a}}$ & 13.2 & 14.0 & 1.38 & 1.40 & 0.41 & 0.42 & $6.89^{\mathrm{a}}$ & $6.86^{\mathrm{ab}}$ \\
\hline Perovskia abrotanoides Kar & $56.6^{\mathrm{e}}$ & $51.8^{e}$ & $63.5^{\mathrm{ab}}$ & $63.0^{\mathrm{a}}$ & $19.8^{b}$ & $18.7^{\mathrm{bc}}$ & 13.5 & 14.6 & 1.22 & 1.32 & 0.45 & 0.43 & $6.91^{\mathrm{a}}$ & $6.85^{\mathrm{ab}}$ \\
\hline Cichorium intybus $\mathrm{L}$ & $63.5^{\mathrm{a}}$ & & $61.6^{\mathrm{bc}}$ & $63.1^{\mathrm{a}}$ & $22.7^{\mathrm{a}}$ & $21.0^{\mathrm{ab}}$ & 13.5 & 13.7 & 1.33 & 1.33 & 0.41 & 0.38 & $6.89^{\mathrm{a}}$ & $6.88^{\mathrm{a}}$ \\
\hline Borago officinalis $\mathrm{L}$ & $59.7^{c}$ & $55.0^{d}$ & $62.0^{\mathrm{abc}}$ & $61.2^{\mathrm{bc}}$ & $22.8^{\mathrm{a}}$ & $21.7^{\mathrm{a}}$ & 13.3 & 13.7 & 1.35 & 1.40 & 0.41 & 0.41 & $6.92^{\mathrm{a}}$ & $6.90^{\mathrm{a}}$ \\
\hline Peganum harmala $\mathrm{L}$ & $63.8^{\mathrm{a}}$ & $60.0^{\mathrm{ab}}$ & $63.3^{\mathrm{ab}}$ & $62.2^{\mathrm{ab}}$ & $18.2^{b}$ & $18.3^{c}$ & 14.5 & 15.0 & 1.47 & 1.40 & 0.49 & 0.48 & $6.89^{\mathrm{a}}$ & $6.86^{\mathrm{ab}}$ \\
\hline Teucrium polium $\mathrm{L}$ & $64.0^{\mathrm{a}}$ & $60.7^{\mathrm{a}}$ & $62.7^{\mathrm{ab}}$ & $63.1^{\mathrm{a}}$ & $19.9^{\mathrm{b}}$ & $19.2^{\mathrm{abc}}$ & 13.6 & 14.3 & 1.35 & 1.22 & 0.38 & 0.45 & $6.82^{b}$ & $6.80^{\mathrm{b}}$ \\
\hline Medicago sativa & $63.9^{\mathrm{a}}$ & $59.9^{\mathrm{ab}}$ & $62.2^{\mathrm{abc}}$ & $62.5^{\mathrm{a}}$ & $19.7^{b}$ & $20.2^{\mathrm{abc}}$ & 14.2 & 14.6 & 1.42 & 1.26 & 0.42 & 0.49 & $6.89^{\mathrm{a}}$ & $6.86^{\mathrm{ab}}$ \\
\hline SEM & 0.55 & 0.62 & 0.27 & 0.19 & 0.40 & 0.33 & 0.14 & 0.16 & 0.028 & 0.024 & 0.014 & 0.014 & 0.0076 & 0.0078 \\
\hline$p$-value & $<0.0001$ & $<0.0001$ & 0.026 & 0.001 & 0.0004 & $<0.0001$ & 0.52 & 0.44 & 0.36 & 0.479 & 0.72 & 0.34 & 0.05 & 0.0006 \\
\hline
\end{tabular}

Means with different letters among the same row indicate significant differences according to the $p$-value presented

TVFA total volatile fatty acids, SEM standard error of the mean

about $30 \mathrm{mg} / \mathrm{kg}$ DM (McDowell 1985). The zinc concentrations of Dracocephalum moldavica L., Melissa officinalis L., Perovskia abrotanoides Kar., Cichorium intybus L., Borago officinalis L., and Teucrium polium L. is more than the critical level (i.e., 38.4-43.1, 48.2-51.1, $31.3-34.6,32-34,73.3-75.7$, and $41.5-46.3 \mathrm{mg} / \mathrm{kg} \mathrm{DM}$, respectively), and those of Ruta graveolens L., Peganum harmala L., and Medicago sativa are less than the critical level (i.e., 24-24.3, 13.9-15, 17.4-20.5 mg/kg DM, respectively) (Table 2).

Three significant mechanisms, including the salivary buffer system, the buffering capacity of the feed consumed, and the dietary additive buffers, can affect the ruminal buffering system in ruminants (Moharrery 2007). Initial $\mathrm{pH}$ and titratable acidity have been reported to be the most critical determinants of rumen fluid $\mathrm{pH}$. In the present study, the highest titratable acidity was observed for Borago officinalis L. $\left(285-344 \mathrm{mEq} \times 10^{-3}\right)$ and Peganum harmala L. (300-327 $\left.\mathrm{mEq} \times 10^{-3}\right)$, indicating high resistance to acidification. Due to the different ash content of the plant species studied in this study $(5.89-15.9 \%)$, their buffering capacity was also different. In line with our study, the buffering capacity of some protein sources and leguminous fodder has been reported higher than $85 \mathrm{mEq} \times 10^{-3}$ (Montañez-Valdez et al. 2013). By evaluating the $\mathrm{pH}$ and buffering capacity of the diet, we can predict the need for buffers to control and maintain rumen $\mathrm{pH}$ (Bujňák et al. 2011). Except for Ruta graveolens L., other plants had near-neutral $\mathrm{pH}$, and therefore, their consumption could not lead to rumen $\mathrm{pH}$ reduction. It is reported that the amount and composition of minerals in the ash have a particular buffering effect on the plant's initial pH (Levic et al. 2005).
In this study, the highest acid and also acid-base buffering capacity in Dracocephalum moldavica L. indicated more acid is needed to change in $\mathrm{pH}$ of the water-soluble plant sample and high control of this plant in ruminal $\mathrm{pH}$ balance.

Even though protozoa include a considerable section of the rumen biomass, their function in ruminal fermentation and their contribution to the metabolism and nutrition of the animal is still an area of substantial controversy (Williams and Coleman 1992). In the present study, we found that the plants including Perovskia abrotanoides Kar., Peganum harmala L., and Teucrium polium L. had an antiprotozoal activity in the culture medium compared to the Medicago sativa. Wright and Phillipson (1990) also reported an antiprotozoal activity of Peganum harmala L. because of its alkaloid compounds. It is reported that Perovskia is a small genus from the Lamiaceae family, which includes a variety of promising medicinal and phytochemical properties (Mohammadhosseini et al. 2019). In line with the present study, an anti-protozoan activity by $\mathrm{n}$-hexane and ethyl acetate extracts from the aerial parts of Perovskia was reported by Tabefam et al. (2018). The antimicrobial effect of alcoholic extracts of Teucrium polium L. was reported by Darabpour et al. (2010). It is reported that some plants such as Teucrium polium L. can produce some antimicrobial substances in themselves (Darabpour et al. 2010). Protozoa predate on bacteria as a major source of protein (Williams and Coleman 1992) and as a result, defaunation makes the rumen more efficient in terms of proteosynthesis, increasing the duodenal microbial protein flow and total non-ammonia nitrogen flow. Therefore, it seems that the reduction of the protozoan 
population due to incubation of Perovskia abrotanoides Kar., Peganum harmala L., and Teucrium polium L. is effective in improvement of animal performance.

When a diet is incubated with buffered rumen fluid in a culture medium, the carbohydrates are mainly fermented to SCFA, microbial cells, and gases (mainly $\mathrm{CH}_{4}$ and $\mathrm{CO}_{2}$ ) (Getachew et al. 1998). Gas production is basically a result of carbohydrates fermentation to acetate, propionate, and butyrate (Beuvink and Spoelstra 1992; Blümmel and Ørskov 1993). We found that Teucrium polium L. had higher potential gas production. Although the increase in gas production due to incubation of Teucrium polium L. can indicate more fermentation in vitro, more gas production cannot always indicate higher quality of forages or be associated with more digestibility because the gas produced in the gas technique is the direct gas produced as a result of fermentation $\left(\mathrm{CO}_{2}\right.$ and $\left.\mathrm{CH}_{4}\right)$ and the indirect gas produced from the buffering of short chain fatty acids $\left(\mathrm{CO}_{2}\right.$ released from the bicarbonate buffer) (Getachew et al. 1998). Several factors such anaerobiosis, proper temperature, suitable $\mathrm{pH}$, and adequate buffering affect the fermentation of feedstuffs by ruminal microorganisms and hence gas production (Getachew et al. 1998). Browse plants and tree fodders contain a valuable source of nutrients for ruminants worldwide. Although these plants can be considered as good sources of valuable nutrients, they often contain different amounts of secondary compositions. Such secondary compositions are known to affect nutrient utilization due to their interaction with nutrients, and also because they influenced ruminal microorganisms (Getachew et al. 1998). Although different secondary compounds were reported for Teucrium polium L. as a medicinal plant (Farahbakhsh et al. 2020; Al-Otaibi and AlMotwaa 2021), the reasons for increased gas production here are unclear for us. A section of increase in potential gas production resulting from Teucrium polium L. incubation may be attributed to its secondary compound. We found that Ruta graveolens L., Cichorium intybus L., and Peganum harmala $\mathrm{L}$. produced a potential gas production almost similar to Medicago sativa. It has been reported that gas production is a reflection of generation of short chain fatty acids (Getachew et al. 1998).

We found a normal pH (6.80-6.92) in the culture medium when plants were incubated. The reported values of pH (Table 6) are within the normal pH (5.8-7.2) that has been reported by Hiltner and Dehority (1983) for favorite ruminal microbial activity. The VFA produced via ruminal microbial fermentation are the primary source of energy absorbed by the digestive tract wall of ruminants and they can affect on animal performance. The efficiency of energy utilization, methane yield, risks of ruminal acidosis, and composition of animal products can be affected by the profile and concentration of VFA (Noziere et al. 2011). In this study, TVFA produced from Ruta graveolens L., Cichorium intybus L., Peganum harmala L., and Teucrium polium L. incubation was approximately similar to Medicago sativa in the culture medium. It has been reported that up to $80 \%$ of maintenance energy required for ruminants is supplied by VFA (Bergman 1990; Baldwin 1998). Therefore, the production of more VFA due to incubation of Ruta graveolens L., Cichorium intybus L., Peganum harmala L., and Teucrium polium L. can be beneficial to the host animal to meet energy requirements. We found that among the studied plants, only, Ruta graveolens L. produced less acetate after incubation. Propionate is an important gluconeogenic substrate for ruminants, whereas acetate is the primary precursor for de novo lipogenesis (Ötztürk et al. 2015). All plants produced suitable propionate concentrations compared to the Medicago sativa.

In summary, many rangeland plant species provide a suitable reserve feed for grazing animals, particularly during the dry season, or fill regular gaps in feed supply caused by seasonal conditions. The data about the chemical-mineral compounds, buffering capacity, in vitro gas production, and in vitro ruminal microbial fermentation characteristics of eight rangeland plants obtained under well situation and similar experimental conditions can be used to optimize diet formulation in terms of nutrients supply to the small ruminants that will ensure better utilization of this nutrients-rich feed resource and will be profitable from an economic point of view for animal husbandries in this region and other similar regions worldwide. Melissa officinalis L. and Peganum harmala $\mathrm{L}$. were found to be a suitable source of CP compared to Medicago sativa. The calcium content of Peganum harmala L. was approximately two times higher than Medicago sativa. Dracocephalum moldavica L. exhibited higher acid-base buffering capacity compared to other plants. More potential gas production was observed in Teucrium polium L. The plants, including Perovskia abrotanoides Kar., Cichorium intybus L., Peganum harmala L., and Teucrium polium L. had anti-protozoan activity. Based on previous reports, Peganum harmala L. might be toxic for animals if it is consumed excessively. Therefore, dietary consumption of this plant should be controlled, especially in younger animals. Variation in the studied parameters among the investigated forages between 2019 and 2020 was negligible. Overall, these results indicate that plant species have relatively high nutritional values hence they can be used as sources of feeds for livestock to improve their production performance. 


\section{Abbreviations}

DM: Dry matter; EE: Ether extract; CP: Crude protein; NDF: Neutral detergent fiber; ADL: Acid detergent lignin; ADF: Acid detergent fiber; NRC: National research council; TDMD: True dry matter digestibility; TVFA: Total volatile fatty acids; VFA: Volatile fatty acids; $b_{\text {gas }}$ : Potential gas production; $c_{\text {gas }}$ : Fractional rate of gas production; NFC: Non-fiber carbohydrates; DMI: Dry matter intake.

\section{Acknowledgements}

This project was supported technically by the University of Torbat-e Jam. The assistance of Mr. Meysam Ilnet, Mr. Mohammad Ghanbari, Mr. Ardeshir Momeni, and Mr. Ali Hamedi for carrying out this project is greatly acknowledged.

\section{Authors' contributions}

This project was conducted and written by MK. Assistance in laboratory analysis was done by MMM. Data analysis and some laboratory activities were conducted by RT. The authors read and approved the final manuscript.

\section{Funding}

This study was funded by the University of Torbat-e Jam.

\section{Availability of data and materials}

The data will be made available upon request.

\section{Declarations}

\section{Ethical approval and consent to participate}

The Animal Ethics Committee at the University of Torbat-e Jam approved all the animal protocols used in the present experiment.

\section{Consent for publication}

Not applicable.

\section{Competing interests}

The authors declare that there was no conflict of interest associated with this manuscript.

\section{Author details}

${ }^{1}$ Department of Animal Science, Faculty of Agriculture and Animal Science, University of Torbat-e Jam, Torbat-e Jam, Iran. ${ }^{2}$ Department of Animal Science, Agriculture Faculty, Herat University, Herat, Afghanistan.

Received: 26 October 2021 Accepted: 15 December 2021

Published online: 22 December 2021

\section{References}

Al-Otaibi WA, AlMotwaa SM (2021) Preparation, characterization, optimization, and antibacterial evaluation of nano-emulsion incorporating essential oil extracted from Teucrium polium L. J Dispers Sci Technol 2021:1-11. https://doi.org/10.1080/01932691.2021.1980000

Ankom Technology (2005) Method for determining acid detergent lignin in Beakers. https://www.ankom.com/sites/default/files/document-files/ Method_8_Lignin_in_beakers_0.pdf. Accessed 8 Jan 2021

Ankom Technology. 2006a. Acid detergent fiber in feeds-filter bag technique. https://www.ankom.com/sites/default/files/document-files/Method_5_ ADF_A200.pdf. Accessed 8 Jan 2021

Ankom Technology. 2006b. Neutral detergent fiber in feeds-filter bag technique. https://www.ankom.com/sites/default/files/document-files/ Method_6_NDF_A200.pdf. Accessed 8 Jan 2021

AOAC (2005) Official methods of analysis, 18th edn. AOAC International, Gaithersburg

Baldwin RL (1998) Use of isolated ruminal epithelial cells in the study of rumen metabolism. J Nutr 128:293S-296S. https://doi.org/10.1093/jn/128.2.293S

Bergman EN (1990) Energy contributions of volatile fatty acids from the gastrointestinal tract in various species. Physiol Rev 70:567-590. https://doi. org/10.1152/physrev.1990.70.2.567

Beuvink JMW, Spoelstra SF (1992) Interactions between substrate, fermentation end-products, buffering systems and gas production upon fermentation of different carbohydrates by mixed rumen microorganisms in vitro. Appl Microbiol Biotechnol 37(4):505-509. https://doi.org/10. 1007/BF00180978

Blümmel M, Ørskov ER (1993) Comparison of in vitro gas production and nylon bag degradability of roughages in predicting feed intake in cattle. Anim Feed Sci Technol 40:109-119. https://doi.org/10.1016/0377-8401(93) 90150-।

Bujňák L, Maskal'ová I, Vladimir V (2011) Determination of buffering capacity of selected fermented feedstuffs and the effect of dietary acid-base status on ruminal fluid pH. Acta Vet Brno 80:269-273. https://doi.org/10.2754/ avb201180030269

Darabpour E, Motamedi H, Nejad SMS (2010) Antimicrobial properties of Teucrium polium against some clinical pathogens. Asian Pac J Trop Med 3(2):124-127. https://doi.org/10.1016/S1995-7645(10)60050-8

Dehority BA (2003) Rumen microbiology. Nottingham University Press, Nottingham

Dias MI, Barros L, Sousa MJ, Ferreira IC (2012) Systematic comparison of nutraceuticals and antioxidant potential of cultivated, in vitro cultured and commercial Melissa officinalis samples. Food Chem Toxicol 50(6):18661873. https://doi.org/10.1016/j.fct.2012.03.057

Farahbakhsh J, Najafian S, Hosseinifarahi M, Gholipour S (2020) The effect of time and temperature on shelf life of essential oil composition of Teucrium polium L. Nat Prod Res. https://doi.org/10.1080/14786419.2020. 1771711

Getachew G, Blümmel M, Makkar HPS, Becker K (1998) In vitro gas measuring techniques for assessment of nutritional quality of feeds: a review. Anim Feed Sci Technol 72(3-4):261-281. https://doi.org/10.1016/S03778401(97)00189-2

Getachew G, Robinson PH, DePeter EJ, Taylor SJ (2004) Relationships between chemical composition, dry matter degradation and in vitro gas production of several ruminant feeds. Anim Feed Sci Technol 111:57-71. https:// doi.org/10.1016/S0377-8401(03)00217-7

Ghaffari Z, Rahimmalek M, Sabzalian MR (2018) Variations in essential oil composition and antioxidant activity in Perovskia abrotanoides Kar. collected from different regions in Iran. Chem Biodivers 15(6):e1700565. https://doi. org/10.1002/cbdv.201700565

Habib G, Khan NA, Sultan A, Ali M (2016) Nutritive value of common tree leaves for livestock in the semi-arid and arid rangelands of Northern Pakistan. Livest Sci 184:64-70. https://doi.org/10.1016/j.livsci.2015.12.009

Hall MB, Herejk C (2001) Differences in yields of microbial crude protein from in vitro fermentation of carbohydrates. J Dairy Sci 84:2486-2493. https:// doi.org/10.3168/jds.S0022-0302(01)74699-1

Harper KJ, McNeill DM (2015) The role iNDF in the regulation of feed intake and the importance of its assessment in subtropical ruminant systems (the role of iNDF in the regulation of forage intake). Agriculture 5(3):778790. https://doi.org/10.3390/agriculture5030778

Hiltner P, Dehority B (1983) Effect of soluble carbohydrates on digestion of cellulose by pure culture of rumen bacteria. Appl Environ Microbiol 46(3):642-648. https://doi.org/10.1128/aem.46.3.642-648.1983

Jasaitis DK, Wohlt JE, Evans JL (1987) Influence of feed ion content on buffering capacity of ruminant Feedstuffs in vitro. J Dairy Sci 70:1391-1403. https://doi.org/10.3168/jds.S0022-0302(87)80161-3

Kazemi M (2019) Comparing mineral and chemical compounds, in vitro gas production and fermentation parameters of some range species in Torbat-e Jam, Iran. J Rangel Sci. 9:351-363. http://www.rangeland.ir/artic le_663575_b4c0b90111c197e5f3297398c28eddaf.pdf. Accessed 25 Aug 2021

Kazemi M, Valizadeh R (2019) Nutritive value of some rangeland plants compared to Medicago sativa. J Rangel Sci 9:136-150. http://www.rangeland. ir/article_544497_05cf90b4d9e8f698ff7feae8899ba8d8.pdf. Accessed 18 Sept 2021

Kazemi M (2021). Nutritional value of some rare forage plants fed to small ruminants. Trop. Subtrop. 24:1-10. https://www.revista.ccba.uady.mx/ojs/ index.php/TSA/article/view/3295/1508. Accessed 20 Aug 2021

Kazemi M, Ghasemi Bezdi K (2021) An investigation of the nutritional value of camelthorn (Alhagi maurorum) at three growth stages and its substitution with part of the forage in Afshari ewes' diets. Anim Feed Sci Technol 271:114762. https://doi.org/10.1016/j.anifeedsci.2020.114762

Keim JP, Cabanilla J, Balocchi OA, Pulido RG, Bertrand A (2018) In vitro fermentation and in situ rumen degradation kinetics of summer forage brassica plants. Anim Prod Sci 59(7):1271-1280. https://doi.org/10.1071/AN17534 
Khan ZI, Hussain IA, Ashraf M, Valeem EE, Javed I (2005) Evaluation of variation of soil and forage minerals in pasture in a semiarid region of Pakistan. Pak J Bot 37:921-931

Komolong MK, Barber DG, McNeill DM (2001) Post-ruminal protein supply and $\mathrm{N}$ retention of weaner sheep fed on a basal diet of lucerne hay (Medicago sativa) with increasing levels of quebracho tannins. Anim Feed Sci Technol 92:59-72. https://doi.org/10.1016/S0377-8401(01)00246-2

Levic J, Prodanovic O, Sredanovic S (2005) Understanding the buffering capacity in feedstuffs. Biotechnol Anim Husb 21(5-6):305-313. https://doi.org/ 10.2298/BAH0506309L

Mahmoudi R, Nosratpour S (2013) Teucrium polium L essential oil: phytochemiacl component and antioxidant properties. Int Food Res J 20(4):1697-1701

Makkar HPS (2010) In vitro screening of feed resources for efficiency of microbial protein synthesis. In: Vercoe PE, Makkar HPS, Schlink AC (eds) In vitro screening of plant resources for extra-nutritional attributes in ruminants, nuclear and related methodologies. Springer, Dordrecht, pp 106-144

McDowell LR (1985) Nutrition of grazing ruminants in warm climates. Academic Press, New York, p 443

McDowell LR (1992) Minerals in animal and human nutrition. Academic Press, San Diego

McDowell LR (1997) Minerals for grazing ruminants in tropical regions. University of Florida, Gainesville

McDowell LR, Arthington JD (2005) Minerals for grazing ruminants in tropical regions, 4th edn. University of Florida, IFAS, Gainesville

Menke KH, Steingass H (1988) Estimation of the energetic feed value obtained from chemical analysis and in vitro gas production using rumen fluid. Anim Res Dev 28:7-55

Minson DJ (1990) Forage in Ruminant Nutrition. Academic Press, London, UK Mirzaei F (2012) Minerals profile of forages for grazing ruminants in Pakistan. Open J Anim Sci 2(3):133-141. https://doi.org/10.4236/ojas.2012.23019

Mohammadhosseini M, Venditti A, Akbarzadeh A (2019) The genus Perovskia Kar:: ethnobotany, chemotaxonomy and phytochemistry a review. Toxin Rev. https://doi.org/10.1080/15569543.2019.1691013

Moharrery A (2007) The determination of buffering capacity of some ruminant's feedstuffs and their cumulative effects on TMR ration. Am J Anim Vet Sci 2(4):72-78

Montañez-Valdez OD, Solano-Gama JDJ, Martinez-Tinajero JJ, Guerra-Medina CE, Coss ALD, Orozco-Hernandez R (2013) Buffering capacity of common feedstuffs used in ruminant diets. Rev Colomb Cienc Pec 26:37-41. http:// www.scielo.org.co/pdf/rccp/v26n1/v26a1a6.pdf. Accessed 15 Sept 2021

Newbold CJ, De La Fuente G, Belanche A, Ramos-Morales E, McEwan NR (2015) The role of ciliate protozoa in the rumen. Front Microbiol 6:1313. https://doi.org/10.3389/fmicb.2015.01313

Nocek JE, Tamminga S (1991) Site of digestion of starch in the gastrointestinaltract of dairy-cows and its effect on milk-yield and composition. J Dairy Sci 74:3598-3629. https://doi.org/10.3168/jds.S0022-0302(91)78552-4

Noziere P, Glasser F, Sauvant D (2011) In vivo production and molar percentages of volatile fatty acids in the rumen: a quantitative review by an empirical approach. Animal 5(3):403-414. https://doi.org/10.1017/S1751 731110002016

NRC (2007) Nutrient requirements of small ruminants: sheep, goats, cervids, and new world camelids. National Academic Press, Washington (DC)

Ørskov ER, McDonald I (1979) The estimation of protein degradability in the rumen from incubation measurements weighted according to rate of passage. J Agric Sci 92:499-503. https://doi.org/10.1017/S002185960 0063048

Öztürk H, Demirbaş YS, Aydin FG, Pişkin I, Ünler FM, Emre MB (2015) Effects of hydrolyzed and live yeasts on rumen microbial fermentation in a semicontinuous culture system (Rusitec). Turk J Vet Anim Sci 39(5):556-559. https://doi.org/10.3906/vet-1506-16

SAS (2002) Statistical analysis system. User's guide: statistics. SAS Institute, Cary

Sniffen CJ, O'Conno JD, Van Soest PJ, Fox DG, Russell JB (1992) A net carbohydrate and protein system for evaluating cattle diets. II. Carbohydrate and protein availability. J Anim Sci 70:3562-3577. https://doi.org/10.2527/ 1992.70113562x

Spears JW (1994) Minerals in forages. Forage Quality Evaluation Utilization. https://doi.org/10.2134/1994.foragequality.c7

Tabefam M, Farimani MM, Danton O, Ramseyer J, Kaiser M, Ebrahimi SN, Salehi P, Batoli H, Potterat O, Hamburger M (2018) Antiprotozoal diterpenes from
Perovskia abrotanoides. Planta Med 84(12/13):913-919. https://doi.org/ 10.1055/a-0608-4946

Underwood EJ, Suttle NF (1999) The mineral nutrition of livestock, 3rd edn. CABI Publishing, New York

Van Soest PJ (1994) Nutritional ecology of the ruminant. Cornell University Press, Ithaca

Williams AG, Coleman GS (1992) The rumen protozoa. Springer-Verlag, New York

Wright CW, Phillipson JD (1990) Natural products and the development of selective antiprotozoal drugs. Phytother Res 4(4):127-139. https://doi. org/10.1002/ptr.2650040402

\section{Publisher's Note}

Springer Nature remains neutral with regard to jurisdictional claims in published maps and institutional affiliations.

\section{Submit your manuscript to a SpringerOpen ${ }^{\odot}$ journal and benefit from:}

- Convenient online submission

- Rigorous peer review

- Open access: articles freely available online

- High visibility within the field

- Retaining the copyright to your article

Submit your next manuscript at $\boldsymbol{\nabla}$ springeropen.com 